\title{
Preliminary Study of Some Insects Associated with Range- land Shrubs with Emphasis on Kochia Prostrata
}

\author{
T. BLAINE MOORE, RICHARD STEVENS, AND E. DURANT MCARTHUR
}

\section{Abstract}

The introduced and potentially useful range shrub Kochia prostrata (prostrate kochia) and its naturalized herbaceous congener $\boldsymbol{K}$. scoparia (annual kochia) both appear to be excellent hosts for the lygus bug (Lygus desertinus). However, lygus bugs were abundant only on concentrated Kochia stands and not on $K$. prostrata growing intermixed with other plant species. Therefore, it is recommended that prostrate kochia be planted in mixtures with other plant species in range rehabilitation projects so that high insect populations are not encouraged. Lygus bugs spend much of the summer on both Kochia species but move to associated plants when the associates flower. Although lygus bugs were found in abundance on prostrate kochia, no major damage to the plant was evident. Prostrate kochia apparently is not the overwintering egg host-plant for lygus bugs. On prostrate kochia, seven other identified insect species (six families) as well as several unidentified taxa were also collected. These additional species were mostly short-time residents in low numbers. Flea beetles (Psylloides punctulata) were occasionally abundant.

In the semiarid Intermountain West, the reclaiming of ranges by seeding is an important objective of state and federal agencies and private individuals. An introduced semishrub, prostrate kochia (Kochia prostrata), shows promise of fulfilling many restoration needs (Keller and Bleak 1974; McArthur et al. 1974, 1978; Britton and Sneva 1977; Davis 1979; Frischknecht and Ferguson 1979). The Russians recognized the value of this plant for forage as early as 1923 (Balyan 1972). Soviet scientists more recently have been conducting experimental studies on morphology, taxonomy, physiology, and nutritive quality of prostrate kochia (Balyan 1972; Shamsutdinov and Nazaryuk 1978). A native of much of Eurasia (central Europe to Manchuria), it has been seeded in several parts of the Soviet Union and in neighboring countries (Shishkin 1936: Balyan 1972; Nemati 1977; Moghaddam 1978).

The literature shows little has been done with insects inhabiting prostrate kochia. Balyan (1972) reported prostrate kochia to be resistant to disease and insects. Gegechkori (1975) reported Trioza kochiae and T. bathiashvillii on prostrate kochia growing in the semidesert regions of eastern Georgia and the Khosro state pre-

\footnotetext{
Authors are biological technician, Intermountain Forest and Range Experiment Station. and professor of biology, Snow College, Ephraim, Utah 84627; game biologist, Utah Division of Wildlife Resources, Ephraim, Utah 84627; and principal research geneticist, Intermountain Forest and Range Experiment Station, Ogden, Utah 84401 , stationed at the Shrub Sciences Laboratory, Provo, Utah 84601 .

The Snow Field Station located at Ephraim, Utah, is cooperatively maintained by Utah State University, Snow College, the Intermountain Forest and Range Experiment Station, and the Utah Division of Wildlife Resources.

Federal aid in wild life restoration funds was provided through Pittman-Robertson Project W-82-R.

Authors thank J.B. Karren and B.A. Haws of Utah State University for their valuable help at various stages in this project. A.H. Barnum. M.M Furniss, and C.F. Tiernan also provided counsel and advice.

Manuscript received April 14, 1980.
}

serve of Armenia U.S.S.R.

In some test plantings of prostrate kochia in Utah, substantial insect numbers were observed inhabiting this introduced shrub. To have a better understanding of the insects that are associated with prostrate kochia, a project was started to determine how many and what kinds of insects had an affinity for it.

\section{Methods}

Spot checks for insects on prostrate kochia were made in 1977 to see which insects werc present. Many lygus bug, (Lygus desertinus), flea beetles (Psylloides punctulata), and leaf hoppers (Cicadellidae) were present on prostrate kochia during the months of June and July.

In 1978, three collection stations were set up in plantings of prostrate kochia on the Snow Field Station, Ephraim, Utah. Other plantings of prostrate kochia (Santa Clara, Washington County, Utah; Gordon Creek, Carbon County, Utah; and seven locations in Sanpete County, Utah) were checked occasionally for insects. Quantitative studies were made at the Snow Field Station collection stations. Collections were made at intervals between June 4 and October 28 by taking 10 sweeps with an insect aerial net (ring diameter $=30 \mathrm{~cm}$ ). This amount of sweeping consistently covered 3 $\mathrm{m}^{2}$ of plant cover. The number of insects was counted by species and recorded for each station and collection date (Table 1). Checks for insects on associated plants were also made in an effort to make a preliminary assessment of insect movement to and from prostrate kochia.

\section{Results and Discussion}

Insect numbers found in 1977 suggested that two species of insects were sufficiently abundant to warrant further investigation. They were the tiny flea beetles and lygus bugs. Flea beetles, however, were only sporadically abundant in 1978 (Table 1). During 1977 , the flea beetles were on the plants until late June and then suddenly disappeared. Other insect species were found both years in small numbers. Many were either pollen feeders or insect predators. Substantial numbers of lygus bugs remained on the plants until October (Table 1).

Before the shrubs were in bloom in early summer of 1978 at the Snow Field Station, many plant species were checked for insects. Lygus bugs were found in significant numbers on prostrate kochia, but no specimens were picked up on other shrubs in the area. As soon as white rubber rabbitbrush (Chrysothamnus nauseosus albicaulis) began to bloom (September-October), many insects could be found on the flowers of this species. The white rubber rabbitbrush not yet in bloom was devoid of insects. The number of lygus bugs on the rabbitbrush was high and quite constant during the 


\begin{tabular}{|c|c|c|c|c|c|c|c|c|c|c|c|c|c|c|c|c|}
\hline $8^{\tilde{\Xi}}$ & 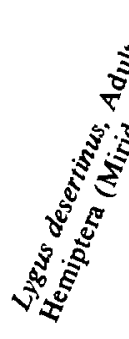 & 要 & 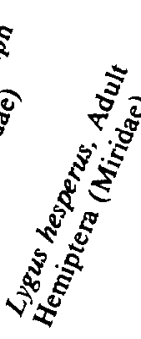 & ڤ" & 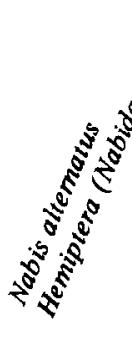 & 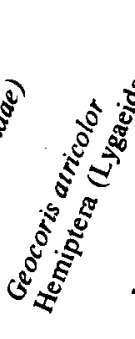 & 党 & 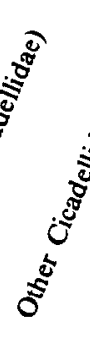 & $\frac{0^{3}}{3}$ & हो & 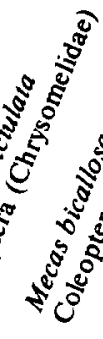 & تే & 密 & $\underset{5}{5}$ & 荵 & $0^{0}$ \\
\hline \multicolumn{17}{|l|}{$\begin{array}{l}1978 \\
3 / 22\end{array}$} \\
\hline $5 / 5$ & 0 & 0 & 0 & 0 & 0 & 0 & 0 & 0 & 0 & 0 & 0 & 0 & & 0 & 0 & 0 \\
\hline $6 / 4$ & 15 & 0 & 0 & 0 & 0 & 0 & 0 & 8 & 1 & 0 & 1 & 0 & & 0 & 0 & 0 \\
\hline $6 / 7$ & 15 & 0 & 0 & 0 & 0 & 0 & 0 & 56 & 0 & 80 & 0 & 0 & & 0 & 0 & 2 \\
\hline $6 / 12$ & 12 & 25 & 3 & 90 & 0 & 0 & 2 & 6 & 0 & 0 & 0 & 0 & & 2 & 0 & 0 \\
\hline $6 / 23$ & 22 & 6 & 4 & 16 & 2 & 2 & 1 & 28 & 1 & 3 & 0 & 2 & & 1 & 2 & 0 \\
\hline $7 / 3$ & 25 & 4 & 2 & 58 & 2 & 1 & 9 & 40 & 1 & 6 & 0 & 2 & & 3 & 10 & 0 \\
\hline $7 / 11$ & 60 & 0 & 1 & 1 & 1 & 0 & 0 & 50 & 0 & 104 & 0 & 0 & & 0 & 0 & I \\
\hline $7 / 17$ & 80 & 17 & 2 & 58 & 1 & 1 & 0 & 13 & 1 & 2 & 0 & 3 & & 2 & 6 & 0 \\
\hline $7 / 29$ & 63 & 54 & 0 & 12 & 3 & 1 & 0 & 0 & 3 & 0 & 0 & 1 & & 0 & 5 & 0 \\
\hline $8 / 2$ & 78 & 69 & 4 & 27 & 4 & 9 & 0 & 2 & 0 & 0 & 0 & 0 & & 3 & 7 & 0 \\
\hline $8 / 15$ & 47 & 121 & 3 & 8 & 2 & 4 & 0 & 0 & 0 & 2 & 0 & 0 & & 2 & 5 & 0 \\
\hline $8 / 19$ & 204 & 0 & 0 & 0 & 0 & 0 & 0 & 0 & 0 & 0 & 0 & 0 & & 0 & 0 & 0 \\
\hline $8 / 28$ & 33 & 20 & 1 & 12 & 3 & 4 & 2 & 0 & 0 & 0 & 0 & 0 & & 1 & 1 & 0 \\
\hline $9 / 13$ & 16 & 0 & 0 & 0 & 0 & 0 & 0 & 0 & 0 & 0 & 0 & 0 & & 0 & 0 & 0 \\
\hline $10 / 4$ & 10 & 0 & 0 & 0 & 4 & 0 & 0 & 0 & 0 & 0 & 0 & 0 & & 0 & 0 & 0 \\
\hline $10 / 28$ & 0 & 0 & 0 & 0 & 1 & 0 & 0 & 0 & 0 & 0 & 0 & 0 & & 1 & 2 & 0 \\
\hline
\end{tabular}

complete flowering period. No immature lygus bugs were found on rabbitbrush. On the prostrate kochia during this same period, there were at least half as many nymphs as there were adult insects, and, on occasions, many more.

Checks were subsequently made on basin big sagebrush (Artemisia tridentata tridentata), black sagebrush ( $A$. nova), oldman wormwood (A. abrotanum), silver sagebrush (A. cana), Pacific aster (Aster chilensis adscendens), and several less abundant shrubs, grasses, and forbs that were not in bloom. Lygus bugs were found only on the aster. Many shrubs were checked periodically throughout the remainder of the summer and fall. Lygus bugs were found on each species only during their flowering period. Prostrate kochia did not bloom until August, but the lygus bug numbers were high through July and August, indicating that the attraction of these insects for prostrate kochia is not limited to the flowering period.

In late June a large patch of annual kochia (Kochia scoparia) was observed near Snow Field Station and lygus bugs were abundant, perhaps more so than on prostrate kochia. A check on another patch about $1.6 \mathrm{~km}$ away showed lygus bugs were as abundant there as on any patches of prostrate kochia. Lygus bugs were equally abundant on both Kochia species throughout the summer.

At the Mercury, Nevada, atomic test site, Knight (1968) reported lygus bugs were frequently found on prin'ess plume (Stanleyea pinnata) and low rabbitbrush (C. viscidiflorus). Lygus bugs also occurred on 22 additional species of forbs and shrubs. Knight's study was taxonomic; therefore, it is assumed that insects were collected only when the plants in question were flowering. The lygus bugs at the Mercury site were most abundant during June, and declined in July and August, until only one specimen was taken in October. The lygus bugs at Mercury may be adapted to avoid the extreme desert heat, thus indicating that the species completes its life cycle early in the year in synchrony with the nondormant phases of many resident plant species.

At our stations, numbers of lygus bugs on prostrate kochia remained high from June through August, with the greatest number present on August 19 (Table 1). Knight's experience with collecting indicated that most mirid adults could be picked up only during the brief flowering period; they appear during this time and when dormant plants start new growth. Lygus nymphs feed on the tender leaves of the host plant, passing through their nymphal instars, and become mature at about the time the plant is in bloom (Knight 1968).

Among the plant feeding mirids, the greater number of species is apparently limited to a single host species or genus. A few have a wide range of food plants. Even among species that breed on a single host plant, a general dispersal usually takes place. At the time of emergence and mating, individual females of the lygus bug will scatter to various plants near the host where they developed, but they will probably not feed on these plants (Knight 1968).

Knight (1968) stated that most members of the family Miridae have a one-year life cycle, but some are known to have two generations per year, and in rare cases, three or four. When two generations are produced within a year, the host plants are those producing succulent growth throughout the growing season. With these types of plants, the tiny nymphs find a maximum amount of sap for food. This was confirmed in the current study. The fact that nearly all nymphs found were on prostrate kochia indicates that this species most likely provides essential nutrients for instar development. According to Moghaddam (1978), high water reserves occur in the leaves of prostrate kochia, which could provide essential water and food requirements for the nymphs.

In September 1978, efforts were made to see if lygus eggs were present in the stems of prostrate kochia. A large number of wounds were found on stems and leaves. When 200 stems and associated leaves were checked, none had eggs in them. The difference between the oviposition wounds and feeding wounds could not be determined without positive evidence of the presence of eggs. Since the proboscis is used to prepare the way for the ovipositor, presumably the two different functional types of wounds would be very similar. We expected that the feeding wounds would produce dead plant tissue in their immediate vicinity. This phenomenon, however, was not observed from the outside of the stems and leaves, nor was excessive discloration noted.

Single species stands of prostrate kochia and annual kochia look to be excellent hosts for lygus bugs. Haws et al. (1973) reported a 
similar relationship between the blackgrass bugs (Labops spp.) and single species grass seedings in Utah. Prostrate kochia plantings with $1-\mathrm{m}$ spacing provided ideal microclimates of humidity, temperature, and protection for the lygus bugs at Snow Field Station, resulting in high bug numbers. Lygus bugs would not have the same ideal environment if plants were scattered and intermixed with other species. This was confirmed in checks of outplantings where prostrate kochia was growing intermixed with other species and lygus bugs were absent or in low num ${ }^{2}$

\section{Conclusions}

Prostrate kochia and annual kochia, in concentrated stands, proved to be excellent host plants for lygus bugs. Lygus bugs were absent or in very low numbers in areas where prostrate kochia was intermixed with other species. Because prostrate kochia is an introduced species that appears to have range improvement potential in the Intermountain West, additional insect plant relationship information is needed.

\section{Literature Cited}

Balyan, G.A. 1972. Kochia prostrata and its culture in Kirghizia. Izdatel 'stvo Kirghiz, Frunze, U.S.S.R. 261 p. (Translated by USDA and Nat. Tech. Inf. Center., U.S. Dep. Commerce, No. TT77-59026).

Britton, C.M., and F.A. Sneva. 1977. Production and chemical attributes of Kochia prostrata. p. 12. In: Abstracts of Papers, 30th Annu. Meet., Soc. Range Manage., Denver, Colo. 58 p.

Davis, A.M. 1979. Forage quality of prostrate kochia compared to three browse species. Agron. J. 71:822-824.

Frischknecht, N.C., and R.B. Ferguson. 1979. Revegetating processed oil shale and coal spoils on semi-arid lands. Interim Rep. U.S. Environ. Prot. Agency. Rep. EPA 600/7-79-068. 47 p.
Gegechkori, A.M. 1975. New Psylloidea (Homoptera) from transcaucasia. Soobshch Akad Nauk Gruz SSR. 78:477-480.

Hawks, R.B., and A. Mayfield. 1976. Some host specificity and biology studies of Coleophora parthenica Meyrick (Lepidoptera: Coleophoridae), an insect for the biological control of Russian thistie. p. 37-43. In: Univ. Idaho, Dep. Entomol. Anniv. Publ. No. 6.

Hawks, R.B., and A. Mayfield. 1978. Coleophora klimeschiella, biological control agent for Russian thistle: host specificity testing. Environ. Entomol. 7:257-261.

Haws, B.A., D.D. Dwyer, and M.G. Anderson. 1973. Problems with range grasses: Look for black grass bugs! Utah Sci. 34:3-9.

Keller, W., and A.T. Bleak. 1974. Kochia prostrata: a shrub of western ranges? Utah Sci. 35:24-25.

Knight, H.H. 1968. Taxonomic review: Miridae of the Nevada test site and the western United States. Brigham Young Univ. Sci. Bull. Biol. Series, 9. $282 \mathrm{p}$.

McArthur, E.D., B.C. Giunta, and A.P. Plummer. 1974. Shrubs for restoration of depleted ranges and disturbed areas. Utah Sci. 35:28-33.

McArthur, E.D., A.P. Plummer, and J.N. Davis. 1978. Rehabilitation of game range in the salt desert. p. 23-50. In: Wyoming Shrublands, Proc. 7th Wyo. Shrub Ecol. Workshop. K.L. Johnson (ed.). Univ. Wyoming, Laramie. $58 \mathrm{p}$.

Moghaddam, M.R. 1978. Kochia prostrata a plant material for range improvement in arid and semi-arid regions. Rangeman's J. 5:153-155.

Nemati, N. 1977. Comparative palatability of Atriplex canescens. J. Range Manage. 30:368-369.

Shamsutdinov, Z.S., and L.A. Nazaryuk. 1978. The problem of desert fodder plant selection. Probl. Osvo Pustyn' (5):3-13 (Biol. Abstr. 67(6) 1979-Entry 32321).

Shishkin, B.K. 1936. Volume VI. Centrospermae. 731 p. In: V.L. Komarov (ed.) Flora of the U.S.S.R. Izatel'stvo Akademii Nauk SSSR. MoscowLeningrad. (Translated by Smithsonian Inst. and Nat. Sci. Found., Washington, D.C. 1970. Available from U.S. Dep. Commerce. No. TT69-5503). 